\title{
Social Context of the fujo: Shamanism in Japan through a Female Perspective
}

Iva LAKIĆ PARAĆ

\begin{abstract}
This study deals with the phenomenon of shamanism in Japan with the emphasis on the female perspective and the fact that women, in the first place, have dealt with shamanistic practices in Japan since ancient times. Could we say that shamanism was a tool that women used in order to have a small part of their authority and power acknowledged? Have they managed to influence their marginal position in society and in what way? Considering the phenomenon from the historical perspective, we will try to individualize some forms in which shamanism in Japan adjusted to the given cultural and social frameworks.
\end{abstract}

Keywords: Japanese shamaness, fujo, ogamisama, kamisama, New religious movements

\section{Izvleček}

Ta študija se ukvarja s fenomenom šamanizma na Japonskem s poudarkom na ženskem vidiku in z dejstvom, da so se ženske že od vsega začetka ukvarjale s šamanskimi praksami na Japonskem. Ali lahko rečemo, da je bil šamanizem orodje, ki so ga ženske uporabljale, da bi le imele priznano majhno vlogo njihove avtoritete in moči? Ali jim je uspelo na takšen način vplivati na njihovo marginalno pozicijo $\mathrm{v}$ družbi? S preučevanjem tega fenomena iz zgodovinske perspektive bomo poskusili individualizirati nekatere oblike, $\mathrm{v}$ katerih se je šamanizem na Japonskem prilagodil na dane kulturne in družbene okvirje.

Ključne besede: japonska šamanka, fujo, ogamisama, kamisama, nova religiozna gibanja

\footnotetext{
* Department for Indology and Far East Studies, Japanology Department, Faculty of Humanities and Social Sciences, University of Zagreb, Zagreb, Croatia.
} 


\section{Introduction}

Shamanism, as a societal and social phenomenon, has become an important topic of anthropological and religious studies in the past decades. This has also been affected by an interest in new religious movements which find inspiration in these ancient shamanistic practices and beliefs. Actually, shamanism has shown a surprising power of adjustment to the new urban contexts worldwide (Morris 2006, 14). Many contemporary new age practices in Europe include elements of shamanism into their beliefs and rituals. In a similar way, new religions in Japan, which will be dealt with in this study, often resort to the imaginaries of the local shamanistic practices and beliefs.

Before the introduction of Buddhism from the Asian continent, mediums had taken the central place in the religious world of the Japanese. They belonged to a separate, honourable class, and ordinary people acted according to their prophecies and advice (see Nakamura 2012). This continues today, especially in the less accessible rural areas where social changes throughout history have been accepted and assimilated less easily (see Lakić Parać 2013). Today, Japan is one of the most technologically developed countries in the world, but sorcery and prophecies (somehow more easily assimilated to the under-developed and poor societies) or something similar, are still popular.

Since the time of prehistoric hunting societies of the Upper Palaeolithic period, shamanism has existed on the Asian continent as a form of belief which endowed particular individuals with the gift of magical powers and of dealing with evil spirits, and as such, it appears in old Japanese folk beliefs. That is why the terms "shaman" and "shamanism" are often used in Japan for describing some characteristics of autochthonous beliefs (Matsumura 2006, 136). However, the active presence of Japanese pre-Buddhist folk beliefs in modern Japan is the evidence of new religious movements, a few of which have typical shamanistic characteristics. Many of them appeared after the Second World War as a response to the state and social crisis which followed the defeat and occupation. It was a period when old religions did not manage to satisfy spiritual needs of Japanese people anymore.

This study deals with the phenomenon of shamanism in Japan. The emphasis will be on the female perspective of the phenomenon and the fact that women, in the first place, have dealt with shamanistic practices in Japan since ancient times, 
having in mind the rigid patriarchal social milieu where women, even today, do not have equal status with men. It is significant that a general term in the Japanese language for a shamaness is "miko", while for shamans this specific term does not exist (Hori 1968, 181). The term fujo 巫女 consists of an ideograph $f u$ 巫 ("shaman") and jo 女 ("woman", “female") and it literally means "a female shaman", while miko (神子 or 巫子) consists of ideographs $m i$ and $k o$ and means "a child of kami" and "a child shaman". Even though in Japan not only women, but also men (although in smaller number), dealt with non-institutional religiousmagical practices, both terms refer to women, i.e. she- shamans.

Could we say that shamanism was a tool that women used in order to have a small part of their authority and power acknowledged? Have they managed to influence their marginal position in society and in what way? Considering the phenomenon from the historical perspective, we will try to individualize some forms in which shamanism in Japan adjusted to the given cultural and social frameworks.

\section{Definitions of Shamans and Shamanism}

The word shaman originally belongs to the language of the Evenkis, the people from the east part of Siberia, and it represents a person (medium) who communicates with spirits (saman). It is assumed that the word is derived from the root of an Indo-European verb sa or "know" (like samana in Pali language or sapere in Italian). Shamanism implies believing in spirits who reside in different objects or natural occurrences. They are imagined as "human beings or persons" in a particular context. Spirits appear and manifest themselves in people's dreams in an animal or bird form, as masked dancers, or are embodied in objects like talismans, trinkets, and similar figures. A shaman or a medium perpetuates a liaison between the world of people and the world of spirits, and the communication takes place when he enters different "alternative states of mind", ecstatic states like trances, ecstasies or "out-of-body" experience ${ }^{1}$. Lewis defines a shaman "an inspired prophet or leader, a charismatic religious figure with the power to control the spirits, usually incarnating them" (as quoted in Lewis 1986, 88). Many say that shamanism is as old as the humankind because it springs from

\footnotetext{
${ }^{1}$ Astral projections and translocations of a subjective spiritual person without the use of the physical body. (see Vukelić 2012, 168)
} 
the ancient human quest "for existential meaning" (Morris 2006, 16). Therefore, it has always helped people to face and solve serious existential problems. It exists in order to "establish interaction with the world of spirits, with the aim of realizing benefits in the material world" (Morris 2006, 17).

The first description of a shamanistic séance can be found in the writings of a Franciscan priest who visited the Mongolian court in the $13^{\text {th }}$ century (Morris 2006, 17), but even older testimonies are found in the Chinese historiography $\mathrm{Wo}_{\mathrm{o}}$ jenchuan from the $3^{\text {rd }}$ century and in the Japanese novel Genji monogatari from the $11^{\text {th }}$ century. Later (European) testimonies are usually written by Russian missionaries and travellers in the $18^{\text {th }}$ and $19^{\text {th }}$ centuries, which is why Siberian shamanism became the subject of European imaginaries, and the shamanic figure was portrayed in various ways: as a daemon, sorcerer, wizard, etc. However, today we know that shamanism is not limited only to Siberia and Eurasian context, but it is a phenomenon spread throughout the world, from North and South America to South-east and Far East Asia, Oceania and Africa. However, we should keep in mind that there are different definitions of shamanism, so the aforementioned interpretation depends on the definition we are using. The prevailing opinion among the theoreticians of shamanism is that its main characteristic is ecstasy, which implies a specific psychical and physical state (trance) which is achieved by means of elaborating implementation of special techniques, cosmic events of which the existence is explained by culturally and mythically based interpretations, occur during the ecstatic state, when the soul of the shaman, according to the belief, deserts his body and goes to the sky or the underworld (Eliade 1985, 30-31; Dubois 2009, 109; Hultkrantz 1997, 37, 42; Winkelman 1999, 394, 402, 411).

The most famous attempt in analysing the phenomenon was made by Mircea Eliade (1907-1986) in his cult book Shamanism: Archaic Techniques of Ecstasy (1964). Eliade approached the issues of shamanism in a phenomenological way, failing to relate it to outer sociological and psychological factors, and in this way, isolating it from the cultural context and the historical moment. He claimed that the attempt to understand the meaning and the essence of religious moments by relating them to sociology and psychology cannot be wrong and limiting. However, many criticize the way he preferred his own "limiting" psychological approach in the analysis of shamanism, and the fact that he spent a lot of energy on explaining the examples of "alternative states of mind", differences between the ecstasy (or 
trance), out-of-body experience (soul flight) and spirit possession (see Morris 2006).

Eliade explained it in this way:

Ecstasy always involves a trance, whether symbolic or pretended or real, and the trance is interpreted as temporary abandonment of the body by the soul of the shaman. During ecstasy, the soul of the shaman is thought to ascend to Heaven, or to descend to the other world (netherworld) or to travel far away into space... Since the ecstasy (trance, losing one's soul, losing consciousness) seems to form an integral part of the human condition, just like anxiety, dream, imagination, etc., we do not deem it necessary to look for its origin in a particular culture or in a particular historical movement. As an experience, ecstasy is a non-historical phenomenon; it is a primordial phenomenon in the sense that it is coextensive with human nature. Only the religious interpretation given to ecstasy and the techniques designed to prepare it or facilitate it are historically conditioned. That is to say, they are dependent on various cultural context, and they change in the course of history. (Eliade in Hori 1968, 185)

Not everyone can become a shaman:

In Central and North-East Asia the chief methods of recruiting shamans are: (1) hereditary transmission of the shamanic profession and (2) spontaneous vocation (call or election). There are also cases of individuals who become shamans of their own free will... or by the will of the clan... However selected, a shaman is not recognized as such until after he has received two kinds of teachings: (1) ecstatic (dreams, trances, etc.) and (2) traditional (shamanic techniques, names and functions of the spirits, mythology and genealogy of the clan, secret language, etc.). (Eliade in Hori 1968, 184)

In his book Ecstatic Religion Ioan Lewis offers a sociological interpretation of shamanism in the manner of structural-functional tradition which still, according to his interpretation, must not exclude the social and historical context. As he explains, his aim is "to isolate the particular social and other conditions which encourage the development of an ecstatic emphasis in religion" (Lewis in Morris 2006, 22). Accepting the structural-functional methods and not forgetting the social context, he concludes that the analyses which treat religion as "a thing in itself and with its own life" are equal to the theological perspective and the modern interest in the occult (Lewis in Morris 2006, 22).

On the basis of his field research in Africa (Somalia, Kenya), Lewis (2003) concluded that altered states of mind, like a trans or an ecstasy, appear in different 
social contexts, secular and religious alike, and are not always related to spirit possession of the body, but can be interpreted in various ways. He gives an example of African warriors who fall into trances in particular occasions, and such behaviour is interpreted as a culturally conditioned response to the dangers and anxieties they are exposed to, with no mystical interpretation whatsoever. On the other hand, in many social contexts spirit possession does not include altered states of mind, and Lewis gives an example of an Indian shaman who, having been invited to establish communication with a local deity, consciously answers all the questions referred to him, even though he should be in the state of trance. Therefore, the questions which should be asked, and which we will try to answer in this study, consider the way events and specific things in everyday life and perception are interpreted and conceptualized in a particular social and cultural context. To put it more precisely, the present paper considers what shamanistic practices mean for women in Japan and what enabled them to carry them out in the past and nowadays, and could we say that female shamanism is a culturally conditioned response to a marginal social status of women in the distant and recent past.

\section{Shamanism and Buddhism}

Japanese shamanism was mixed with Buddhism and Shintoism, but it was never institutionalized in the true sense of the word. At the time when Buddhism was introduced in Japan in the $6^{\text {th }}$ century, it had to have a certain shamanistic character so as to spread among people, since in that time shamanistic religious ways were influential. Because of that, some Buddhist sects compromised with shamanistic tendencies and received approval. The most prominent phenomenon in this initial phase of Buddhism was a relatively larger number of nuns compared to monks, which can be explained by the influence female mediums had among people (see Nakamura 2012).

It is interesting how Buddhism modified during its first introduction in Japan under the influence of a specific religious form such as shamanism. Nakamura (2012, 313-14) emphasizes that the orthodox Buddhism generally rejected shamanistic tendencies like magic and incantation (let us recall that the early Buddhism denied spiritual powers characteristic of Brahmans who performed rituals for exorcising ghosts). What is more, it was required that a Buddhist must not believe in dream interpretation, palm reading, horoscopes, and predictions 
from the calls of birds and beasts. On the other hand, Buddhism could not spread among the lower strata of the Japanese, who maintained old shamanistic tendencies without significant change. As pointed out by the author, in every critical moment in Japan when the ruling class was losing control over peasants, primitive or shamanistic tendencies, which lie dormant from the earlier times, emerged in the foreground (Nakamura 2012, 313-14).

How Japanese Buddhism adjusted to the already present people's beliefs on its way of assimilation among wide masses, can be illustrated on the example of believing in evil spirits or goryo which appeared at the end of the $8^{\text {th }}$ century. It was propagated by popular shamanesses, and in the beginning, it consisted of a belief that a spirit of a person who died as a victim of political conspiracy can haunt their living opponents ${ }^{2}$. The monks of the two largest Buddhist sects of that time, Shingon and Tendai, famous for esoteric principles and religious strictness taught only to the chosen ones, practiced exorcism of the very goryo spirits as one of their most prominent practices. By popularizing this belief in the next decades, possibility of emerging of a single vengeful and dangerous spirit spread among common people. Therefore, the relations between the popular shamanesses and Buddhist monks and ascetics grew stronger, so in the medieval Japan, almost all Buddhist priests had a shamaness or her replacement by their side, whom they used during their exorcist rituals as a medium through which the vengeful spirit spoke and sent messages (Hori 1968, 200). In these circumstances, as explained by Hori, the character and the function of Japanese shamanesses changed in many ways and developed through history: ultimately, some of them became professional mediums connected with the sect Shugend $\bar{o}^{3}$ famous for mountain asceticism; some became entertainers, singers or dancers, narrators of famous ballads and epic poems in public, which were some of the popular forms of

\footnotetext{
${ }^{2}$ Such evil spirit was, e.g. Sugawara no Michizane (845-903), a famous poet and a politician who filled numerous significant posts on the court and who participated in making a decision about the abortion of sending ambassadorial mission to China during Tang dynasty in 894 . He was very influential, but, due to political turmoil, he was persecuted and degraded, and he died in isolation. After that, the royal family and the capital were afflicted with numerous calamities: plague, severe weather conditions, floods - all was attributed to his vengeful spirit. In order to appease it, he was posthumously proclaimed Tenjin-sama or a deity of learning; a temple in Kyōto was dedicated to him, as well as many other Shinto temples throughout Japan.

${ }^{3}$ Shugendo is a sect of mountain hermits associated with kannabi shinkō, i.e. beliefs that spirits of the dead, and spirits related to agriculture live in mountains, shamanistic beliefs and practices, Japanese Animism, Chinese Daoism and yin-yang philosophy, and the rituals of esoteric (tantric) Buddhism (Bocking 1996, 184).
} 
entertainment of all social classes in medieval Japan; some became kuchiyosemiko, independent mediums who established communication with the souls of the dead.

\section{Fujo and Its Categories}

The father of Japanese ethnology—its founder Yanagita Kunio (1875-1962) — was the first one who wrote about Japanese shamanesses in his study Fujokō, in the first volume of the magazine Kyōdo kenkyū (Rural Studies). He claims that in preBuddhist Japan there was a belief that $\mathrm{Kami}^{4}$ can possess a chaste maiden (virgin) so that she, consequently, can deliver a child of a kami (Jap, miko). Yanagita believed that this belief from Nara period (710-794) resulted in the focus on two kami: the god, Hachiman-daijin and the goddess, Hime-gami. He also claimed that later transformation resulted in the formation of two roles - that of a central god Hachiman and the woman through whom he speaks, who is his mediatorshamaness (Hori 1975, 234). He also states that in Japanese classics we can find the term tama yori hime, composed of the words, tama (Jap, "soul, spirit"), yoru (Jap, “enter”), and hime (Jap, “a respectful young woman”) (Hori 1975, 234) Therefore, the term denotes a woman selected by a kami.

Historical facts testify that 1500 years ago there was a system of women sovereigns in Japan, who relied on magical charisma, which means that these women were believed to have special powers and to communicate with deities. Later, this system was replaced by a bureaucratic administration derived from Confucianism and Buddhism, but nevertheless, shamanistic practices did not die out and they were transferred from the centre of power to the province, where they kept on serving common people. Hori $(1975,284)$ argues that the reason for this is the fact that in the psychology of common Japanese people there is a deep-rooted sense of trust in such women, so strong, that it makes them see ancient magical charisma in them, and follow their instructions. Even today, says Hori, people from Tōhoku area address female shamans when they are supposed to make an

\footnotetext{
${ }^{4}$ The precise definition of the term "kami" was offered by a famous Japanese theoretician and restorer of Shintoism, Motoori Norinaga (1730-1801): "The word 'kami' refers, in the most general sense, to all divine beings of heaven and earth that appear in the classics. More particulary, the kami are the spirits that abide in and are worshipped at the shrines. In principle human beings, birds, animals, trees, plants, mountains, oceans-all may be kami. According to ancient usage, whatever seemed strikingly impressive, possessed the quality of excellence, or inspired a feeling of awe was called kami." (Tamaru and Reid 1996, 35)

${ }^{5}$ Translated by Lakić Parać.
} 
important decision. When asked why they do it, they say: "Although it all seems illogical, I am restless, if I don't consult miko.” (Hori 1975, 284)

In his interpretation, Hori follows the great authority Yanagita who claims that a woman has a natural inclination towards spirit possession and that it has been her characteristic since ancient times, so the belief in "female power", i.e. "female spiritual power" in Japan has always been widespread, which is testified by many legends of such women which were talked about as real facts. We should keep in mind that Yanagita, developing his theory about shamanesses, did not collect his information in field research, but mostly worked with written historical documents, analysing texts about folk customs. Ultimately, he concluded that a woman becomes a shaman because of "all general psychological and emotional dispositions and character". This interpretation of shamanism in Japan very much influenced next generations of Japanese ethnologists who dealt with this topic. However, when Yanagita describes that people feared and avoided them due to their powers, he does not ask the crucial question as to why a woman alone (or more precisely, her blood) was considered impure in Japanese culture (Jap, kegare) and what were people actually "afraid of". In other words, Yanagita neglects to consider what he calls "the origin of divine possession" in relation to the social and societal context of these women (see Kawamura 2003, 258).

According to a detailed classification created by Nakamura Tarō in his study Nihon fujo-shi (1930) or History of Japanese Shamanesses (Hori 1975, 235) Japanese shamanesses are divided in two groups. The first group is called kan-nagi where miko belongs, and it is associated with Shinto shrines. These shamanesses perform many functions only in certain formal Shinto ceremonies and they lost most of their former functions and techniques. The second group is called kuchiyose $^{6}$ and these are shamanesses who are associated with rural areas. They usually live in a certain village or they migrate form one village to another, according to the needs of their residents. They preserved the so-called ancient

\footnotetext{
${ }^{6}$ Hori writes that they can be recognized under which names kuchiyose-miko in Japan and points out the term ichiko and its many variations: itako (on the northeast of Honshū), ichijo (on the island of Kyūshū), ita (in the south part of central Honshū) and yuta (islands of Ryūkyū and Amami). Stating the claims of Aribe Takashi that the origin of these terms has some etymological similarities and historical links with the terms udagan, utygan, iduan, üdege, which denote a shaman in Altai-Kyrgyz area, he concludes that one of the obvious links with the continent could be the fact that Japanese shamanesses use a bow with one string, called azusa (hence their name azusa-miko or "a shamaness who uses a bow as a special instrument for entering the state of trance") which is the case in Central Asia (Hori 1968, 201).
} 
shamanistic techniques such as sooth saying, trance, communication with the deities and the dead. Shamanesses from the first group are known under the name miko or jinja-miko ("shamans of Shinto shrines"), and the ones from the second group are known under the name ichiko or sato-miko ("city or village shamans"). Shamanesses of these two categories are semi-institutionalized figures: jinja-miko is usually selected from a family in which Shinto traditions are hereditary, while sato-miko becomes a shamaness through certain initiatory trials and trainings under the guidance of their masters (Hori 1968, 182-83).

Kawamura (2003) offered a very elaborate theory about categories of Japanese shamanesses on the example of Tōhoku region in the north-east of Japan. Since every category has a different name depending on the prefecture where it is present $^{7}$, the author chose the categorisation present in Miyagi prefecture: ogamisama and kamisama. Shamanesses from the first category are blind by rule and they deal with the invocation of spirits of the dead (hotoke oroshi) ${ }^{8}$ who speak through them (kuchiyose) ${ }^{9}$, while the ones from the second category have normal sight and they deal with exorcism. In other words, first ones deal with the invocation of spirits of the dead, and the second ones with the invocation of deities, but in reality, practices of these two categories are sometimes mixed. However, the important thing is the journey of becoming a fujo, which is clearly different in these two categories.

Ogamisama were not chosen as a medium by a spirit or a deity, but they were, by their own free will or not, chosen by older shamanesses who taught them everything about "the call". A characteristic of Tōhoku regions is that almost all shamanesses are blind, and it seems that blind girls were predestined for this "vocation". Namely, in order to become ichininmae or "a full-fledged member of society", they had to earn their living. Their education consists of trainings of different disciplines, like pouring cold water over themselves, fasts, purifications, abstinence, and respecting various taboos. Older teachers teach them trance techniques, communication with other-worldly beings and spirits of the dead, soothsaying, but also prayers, magic formulas and liturgies, reciting ballads and stories. After three to five years of apprenticeship, successful overcoming of all

\footnotetext{
${ }^{7}$ Fujo is called itako in Tōhoku region of Aomori prefecture, ogamisama in Miyagi prefecture, onakata in Yamagata prefecture and waka in Fukushima prefecture (see Kawamura 2003).

${ }^{8}$ Hotoke oroshi, hotoke Jap, "spirit"; oriru Jap, "descend" (translated by ILP).

${ }^{9}$ Kuchiyose, kuchi Jap, “mouth”, yoseru Jap, "draw (closer)" (translated by ILP).
} 
temptations and the closing ceremony of initiation which includes symbols of death and rebirth, the apprentice becomes a full-blooded shamaness (Hori 1968, 203-4). In this way she acquires "a profession" by which she can sustain herself, but also contribute to her community.

None of the kamisama did not decide to become fujo in her maiden days, they were all already married and in their twenties, even thirties or older. They all say that kami chose them for this profession. In addition, before becoming a kamisama, they all went through a difficult situation or a crisis, whether it was a particular illness or a psychosomatic disorder ${ }^{10}$, a conflict with her husband, mother-in-law, problems with raising children, poverty, exhausting working conditions, husband's or children's disease. The most common situation is a woman in her thirties or forties, married and a mother, who, besides taking full care of the household, her husband and children, works in the field, engages in a sort of a family business and, actually, actively earns her salary.

When in crisis, these women will first seek help in various medical institutions, but it is very possible that, at the same time, they will try alternative treatment, for example, acupuncture, massage or folk remedies. If nothing gives any result or the situation does not improve, they will turn to local spiritual guides who will treat their problems as a consequence of a malign spirit or a kami whom they will try to appease or exorcise by means of various prayers, memorial rituals or practices of exorcism. However, sometimes even these will not give desired results. In that case, the religious impulse towards a kami or Buddha will intensify, and the person will completely surrender to it, in the sense that she will completely neglect former duties toward her children and husband, household and work, and she will replace her everyday life with the world of faith. Such person will very soon become a subject of mockery and ridicule. She will also be named a lazy one because of neglecting her duties, and people will despise her (Kawamura 2003, 269).

If the woman has stayed faithful to her former family duties and fulfilled them despite visits to the temple or spiritual guides, she will be said to be a woman "of deep faith". However, if she leaves her obligations, her activities will be considered as deviant, and she will slowly be isolated from the rest of the family and the community. "Punished" in this way, a woman feels misunderstood and

\footnotetext{
${ }^{10}$ In medical literature these are defined as "mental and behavioral factors related to disorders and diseases classified at another place" or "psychological factors which affect the health (physical) condition, and they are related to disorders and diseases classified elsewhere" (Koić, Elvira, lect.).
} 
lonely, and she seeks refuge in faith. This is when the kami possession happens. The woman starts to pronounce peculiar formulas, prophesies and to act in an unusual way. She says that a deity sends messages of salvation of the humanity through her, and that her duty is to transmit those messages. However, if she wants to gain recognition for her new role, she must give evidence to the community that her story is authentic. She can do that by curing someone, by correct predictions of a future event of pointing to the place of a lost item. The fundamental difference between an ogamisama and a kamisama is that the first one does not need such evidence, and, after gaining knowledge through ascetic trainings and spiritual practices, she undergoes initiation in form of rituals (kamitsuke) and officially becomes a fujo, while the latter one will have to prove to the people the strength of the being that possessed her, and in that way gain their trust. (Kawamura 2003, 271)

The first possession by a kami is the most important event in the life of both ogamisama and kamisama. The first time ogamisama is possessed is during the initiation ritual kamitsuke. After she had rejected food for twenty-one days and went through various rituals of bathing in cold water, during the kamitsuke ritual the woman is in the state of extreme mental and physical exhaustion. Accompanied by her older teacher and other assistants, as well as the sounds of ritual instruments, like drums, bells, cymbals and the like, the woman starts to utter prayers and texts from sutras. In the atmosphere of huge excitement and great expectations, the woman starts to communicate with Buddha or a kami, who is usually famous at national or local level, or is a patron of, for example, a place where she lives or is celebrated in a nearby shrine or temple. Anyhow, a deity gets in touch with her thanks to her active sacrifice, prayers and the power of faith and, during the ritual, everyone around her makes sure of that. The initiation process of an ogamisama consists of learning prayers and sutras by heart and mastering techniques for invoking spirits, while possession techniques are not learned. Her rituals consist of reciting holy texts and prayers, and thr possession in the shape of kamitsuki does not happen during her shamanistic ritual (Kawamura 2003, 27374). Since ancient times, there is a widespread belief in Japan that prayers and sutras intrinsically have magical power and a kind of spiritual strength. Such belief suits an ogamisama in the sense that she does not have to behave in a different way than usual. 
As for kamisama is concerned, the possession happens suddenly. A woman who prays devotedly for someone's healing or a solution to a problem, visits temples and shrines and deepens her ascetic trainings, at one moment perceives a deity who takes a very important place in her life and is strongly attached to her. Her first possession is sudden and heteronomous, and from that moment her behaviour and speech become "strange", although before the initiation she will undergo various psychosomatic problems which will result in the announcement of "the call". However, in order to be recognized by the community for her complete devotion to faith, she has to show the power of deity which possess her through a specific action, by predicting an important event, by solving someone's problem, finding a lost object, etc. Gradually, the word of her activities will spread and she will start to win the community's trust (Kawamura 2003, 280). In that process her personal psychosomatic problems will slowly disappear and she will, by overcoming those problems and helping others, actually help herself primarily. By attributing her deviant personal and social behaviour to a supernatural effect, she will actually justify it and gain acceptance by the others.

The two categories of fujo do not only differ in circumstances which lead to the initiation into a shamaness, but also in deities which possess them and their relationship with them.

"The job" of ogamisama is hotoke oroshi (invoking spirits of the dead, also called kuchiyose) and harugitō (invoking the kami or kami oroshi). In the case of kuchiyose, a spirit of a recently deceased person is invoked or a ritual takes place during the higan (spring equinox) when a spirit of an important ancestor is invoked. In these rituals fujo invites the spirit of the dead person (hotoke) to possess her and talk through her. Therefore, the words she speaks are not hers, but hotoke's. In these rituals, her personal patron deity (who possessed her during kamitsuke) does not participate (Kawamura 2003, 275).

"The job" of kamisama is invoking various deities, exorcism, prophecies and the like. She does not deal neither with hotoke oroshi nor harugitō. However, as a consequence of a recent great interest in memorial rituals mizuko kuyō, kamisama started perfoming kuchiyose for mizuko. ${ }^{11}$ As a rule, in her shamanistic séances kamisama invites her patron saint who puts his powers to her disposal. Even when

\footnotetext{
${ }^{11}$ Memorial rituals devoted to spontaneously or intentionally aborted human embryos, prematurely born fetuses, babies who died of natural causes immediately after birth, and babies who are victims of infanticide. More details about this topic will be presented later in the text.
} 
she invokes the spirit of the dead who are believed to suffer "on the other side" because they committed a sin during their life, and when she helps them relieve their suffering and achieve bliss (Buddhahood), kamisama invokes her patron saint and maintains their bond strong (Kawamura 2003, 275).

The deity which possessed ogamisama during the initiation ritual will become her personal patron saint, but he will not appear nor participate in her shamanistic séances anymore, while the deity which possessed kamisama will actively partake in her activities.

\section{New Religious Movements in Japan_kamisama Nakayama Miki}

Popularity of Japanese folk pre-Buddhist beliefs in modern Japan is evidenced by new religious movements ${ }^{12}$, few of which have typical shamanistic characteristics. Throughout history they regularly appeared as a response to crisis which would follow big social changes, when old religions which supported the former regime and value system could not satisfy spiritual needs of the Japanese anymore. It is remarkable that many leaders of new religious movements found their inspiration exactly in charismatic figures of shamans, and even more often, shamanesses. We will analyse the example of Nakayama Miki (1798-1887), the founder of Tenrikyō movement.

Miki was born in the family of a village elder (Jap, shoya) and married at the age of 13 , also to the family of a village elder. When she was 20 , her husband Zenbei's concubine tried to kill her and take her place, which Miki interpreted as a heavenly sign. Raised by the principles of a Buddhist school Pure Land ${ }^{13}$ (Jap,

\footnotetext{
${ }^{12}$ Explaining Japanese new religious movements, and comparing them with messianic cults among American Indians and cargo cults of New Guinea, an anthropologist, H. Neil McFarland says: "These cults are examples of socio-religious phenomenon which, for over a half-century, has been reasonably well understood by anthropologists. Among such cults, wherever they have been discovered, there is a remarkably standard pattern of developement in which at least five factors are recurrent: (1) social crisis intensified by an intrusive culture; (2) a charismatic leader; (3) apocalyptic signs and wonders; (4) ecstatic behavior; and (5) syncretic doctrine. The milieu from which they arise, described in the words of anthropologist Margaret Mead, is the "ferment of half-abandoned old and half-understood new'." (Hori 1968, 220)

${ }^{13}$ The belief in Buddha Amida ("The Buddha of Infinite Light"), whose merit can be transferred to people, so that a man, if he truly and honestly believes, could be reborn in his heaven. In this process, honest invoking of Buddha's name, nenbutsu, will be helpful: "Namu Amida Butsu" or "Long live Buddha Amida". Amidism has its origins in India; it reached China in the $4^{\text {th }}$, and Japan in the $9^{\text {th }}$ century. Today, this is the most popular sect in Japan, and it is very popular in other East Asian countries. The legend says that Buddha Amida, while he was still a monk, vowed that, if he becomes
} 
$J \bar{o} \bar{o} \bar{s} h \bar{u}$ ), she was a fervent practitioner of nenbutsu (reciting names of Buddha Amida and the main religious practice of this school). She lived in Tanba region where Shugendō tradition was very strong, so Miki strongly associated herself with their temple.

Motherhood was the biggest motif of Miki's life. She gave birth to six children, five of which were daughters. While she was breastfeeding, she had so much milk, that she could feed children whose mothers could not breastfeed. In 1828 she started taking care of a neighbour's child who got smallpox and almost died. A legend says that Miki begged her two daughters to be sacrificed for the life of this child; the child survived, and her two daughters died (1830 and 1835).

In 1838 , when she was 41 , her only son contracted a serious disease. Miki prayed to Kōbō Daishi, the founder of a large Buddhist school Shingon ${ }^{14}$, and she went on a hundred day's pilgrimage barefoot to the shrine of a local patron saint. Her association with the Shingon school brought her to the centre Isonokami Shugendō, where she met a highly ranked priest, Ichibei. Under his guidance, she started a ten years' religious training which, among else, included mastering shamanistic practices and rituals (Hardacre 1997, 45).

Miki herself witnessed many shamanistic rituals which Ichibei and his miko partner Soyo did for the recovery of her son. Once, while Soyo was absent, Miki took her place. Instead of the prophecy about the sufferings of her son, she addressed her husband, Zenbei, and, on behalf of the deity which possessed her, she said: "I want Miki to become a temple of my residence" (Jap, Miki o kami no yashiro ni morai uketai). On no account could the exorcist exorcise the spirit from her body, so Miki remained possessed for three days during which she sometimes sat still and sometimes shook uncontrollably and threw herself to the floor, uttering various messages in a low, male voice. Her messages were clear: by becoming the temple of the God Tenriō no Mikoto, she would desert all her duties

Buddha, he will create heaven for all who honestly believe in him and who will, due to the depth of their faith, be reborn there after death and worldly life.

${ }^{14}$ Shingon belongs to the esoteric and secret (revealed) school of Buddhism which emphasizes the importance of verbal formulas - mantras, and oral transmission of the doctrine from the teacher to the student. Since only the chosen ones who have went through initiation can enter the core of the doctrine, it is called "the secret Buddhism". The philosophy of esoteric Buddhism has its roots in India in the $1^{\text {st }}$ and the $2^{\text {nd }}$ century. It deals with the idea that Buddha Dainichi Nyorai ("Buddha Great Sun") has two aspects: the real body (a man-Sakyamuni) and the absolute body. However, the phenomenon and the transcendental body are two aspects, two manifestations, same realities of the same principle. These ideas came to China in the $8^{\text {th }}$, and to Japan in the $9^{\text {th }}$ century. 
of the mother and the wife that she used to have in the Nakayama family. Realizing that the spirit does not intend to leave her body, Zenbei agreed to all conditions. Thereby, the possessed state stopped and Tenrikyō movement dates from that day.

A little is known about this woman's life from that day to 1854, when she was proclaimed a living God_kamisama. She was very poor and it seems that she did not have any followers except her family. However, things changed while she was helping her daughter in labours in 1854. She shook her stomach three times, and after that she delivered her baby unusually easily and quickly. When a woman from the neighbourhood heard what happened, she asked for the same treatment, but she got fever which lasted for 30 days after giving birth. When she asked Miki for the reason, the answer was that she made a mistake of sticking to traditional taboos of food and drinks, which meant she doubted her methods. This doubt caused fever. When the same woman got pregnant again the next year, she strictly followed her instructions and avoided food taboos. Consequently, she had an easy childbirth and a quick recovery, which she attributed to Miki's treatment. After that the word spread that Miki was a living God who ensured a safe childbirth. The number of her clients rose rapidly, and consequently, her financial gains, too.

Nakayama Miko found her first followers among women whom she taught the techniques of safe childbirth. By rejecting the taboos related to particular food, tying the stomach, separate hearths and building separate cottages (Jap, obiya) where women stayed during menstruation, she offered her alternative views of these rituals and beliefs.

In fact, the female sexuality and reproduction have always been the "taboo" zone in $\operatorname{Japan}^{15}$ as in other countries of the world. Purity is the main concern in

\footnotetext{
${ }^{15}$ This is evidenced by a Japanese myth about the creation of the world (Japan), where the first attempt of creation is a miscarriage in the true sense of the word. The child is born malformed because it is the fruit of mistake committed by its mother, Goddess Izanami. Namely, she initiated the act of love, which she was not allowed to do-because it is a male role. Because of this, Izanami and Izanagi had to repeat the act of love in the proper way, following the rules of "appropriate" behavior, which approves of male power. This is when a proper conception and life forming can happen-islands which form the Japanese archipelago. It is no coincidence that soon after, Goddess Izanami will go to the afterlife and stay and rule there, while God Izanagi will stay in this world (Raveri 2006, 312). On the other hand, a Buddhist doctrine condemns emotions and sentimentality because they represent the main reason of a person's attachment to existence and the illusion of his or her own self. A woman, too, is condemned, as well as the seductive power of her sexuality, which hinders and alienates a man from his road to meditative path of liberation. Even in old Buddhist texts female sexuality is samsara, the world of existential suffering, the world of desire which keeps
} 
Shintoism and most of the rituals are devoted to purification. Taboo happens when people or things are contaminated by negative forces like death or diseases. Menstruation, childbirth and other states of a female body require elaborate rituals of purification as well. Pregnancy and childbirth have been ritual topics since ancient times, but most data about their ritualization refer to Edo period (16001868). As stated by Hardacre $(1997,20)$, the birth of the first child represented a ritual which brought the woman to the world of completely adult people, to the company of adult women with the knowledge about sexuality. Besides that, the birth of the first child raised her status in the new family and fixed her membership in it. In such context, the figure of midwife ${ }^{16}$ had religious connotations, because she was the one who led the woman (but also a child) through this transition. However, since midwives were not associated with religious institutions, their figure was considered half-religious. She acted in the zone of an outstanding pollution, in the culture which considered everything related to reproduction and woman sexuality as extremely impure. But, at the same time, a pregnant woman who gave birth was a symbol of power, strength, and life. The new religious movement, founded by Nakayama Miki at the end of Edo period will make its own trademark out of this paradox, and offer an alternative way of ritualizing pregnancy and childbirth.

In medieval Japan, midwives were mostly women who had had experience of several childbirths and who lived in the same village as women whom they served, so usually, they did not travel nor deliver babies outside of their region. Due to the belief that childbirth represents transition of the soul from the world of gods into the world of people, a midwife was considered a leader of the soul which transits from a liminal state of inside the womb to a full-fledged member of a human community. The phrase futari de umu "give birth in pair" referred exactly to the central role of a midwife in the process of delivering a child (Hardacre 1997, 22).

A woman's first pregnancy was marked by a ritual which "connected" her to her midwife who would help her deliver the baby. The midwife would tie a broad band (Jap, iwata obi) around the woman's stomach in the fourth or the fifth month of pregnancy, which was accompanied by a big feast in the midwife's honour

beings in captivity in an infinite cycle of rebirth. Female sexual energy is the root of illusion and evil which must be defeated at all costs (Raveri 2006, 313).

${ }^{16}$ Toriagebaasan or torihikibaasan: "an old woman who pulls out" (toru, Jap "take", in this case "deliver") and give a child (to the mother) (ageru, Jap, "give"). (Translated by ILP) 
where she was treated as a guest of honour. A talisman would be tied for the band to ensure a safe childbirth. This talisman was very different in different regions, but it usually contained a part of the husband's clothes. From that moment on, the woman had to respect taboos related to a particular type of food which was forbidden to her (also with many regional differences), as well as to tie the band firmly in order to "prevent the foetus from becoming too big" (Hardacre 1997, 22). In addition, she had to renounce visits to shrines and temples, so that she would not dishonour their deities with her appearance. Religious institutions considered pregnancy and childbirth a private sphere which is of no concern to public interest, and as such, they do not have place in the ethic map of their reflections. However, due to the blood present at childbirth, the mother and the new-born child are marked as impure, as well as the father and fellow villagers, and it was suggested that they refrain from visiting sacred places during days immediately after the childbirth. Men of certain group, like fishermen and lumberjacks even stopped working during that period (Hardacre 1997, 22-26).

It is interesting to pay attention to the moment of woman's pregnancy subjected to the ritual. It is not "the moment of conception"; in medieval Japan it does not draw attention neither in the ritual nor in the ideological sense. Tying an iwata obi represents the moment when pregnancy becomes visible to others, and only since that moment, the woman gets the status of ninpu, "an expectant mother". Additionally, in this moment the fruit of her womb becomes recognized, which can be seen from many names for the foetus which contain ideographs $k o$ or $j i$, which make it human (Hardacre 1997, 23).

Miki, determined to offer to women an alternative realization of pregnancy and childbirth, opposite to the common practice, travelled to many distant villages practicing her methods on expectant mothers and women in labour. In this way she created a community of women interconnected by a common belief. For example, she demanded that an expectant mother should wear a simple obi, not a special one worn only during pregnancy. Her approach to pregnancy and giving birth was called obiya yurushi, which means "leaving the separate cottage". Instead of such traditional beliefs and treatments, she promised a safe delivery of a baby as a result of believing in her and her actions. She treated childbirth as a natural event which does not require the expectant mother to be isolated because of her impure state. She said that a woman could continue with her normal social life immediately after the delivery, and not wait for 75 days, as was the common practice. 
In order to reject the generally accepted and strong concept of pollution after birth, Miki dealt with raising doubts about the idea that women were impure because of menstruation: She used to say:

Look at the pumpkins and eggplants. They bear large fruit because their flowers have bloomed. Without the blooming of flowers, there can be no fruit. Remember that. People say that women are polluted $(f u j \bar{o})$, but they are not at all. Insofar as women and men are both children of god, there is no difference between them. Women must bear children, and it is a hardship. Women's menstruation is a flower, and without that flower, there can be no fruit. (Hardacre 1997, 47)

By describing menstruation and childbirth with these metaphors and associating them with blossoming flowers which is a prelude to fruit creation, Miki dissociated them from the category of the sacred and put them in the category of the common (Hardacre 1997, 47) ${ }^{17}$.

Even though she did not affect a big number of women with her alternative approach to the topics of pregnancy and childbirth, the religious significance of her innovative approach cannot be denied. With her alternative attitudes, Miki announced changes in relationships between sexes, which she ultimately demonstrated through her own example. We could assume that future alternative ways of ritualization of reproductive experience will be in favour of mediating the relationship between a man and a woman, but we will see that it will not always favour women.

\footnotetext{
${ }^{17}$ Buddhism will adapt the already rooted attitude toward a female body and giving birth, and this is best illustrated by Bussetsu daizōshōkyō ketsubonkyō (The Buddha correct sutra on the bowl of blood, or in short Ketsubonkyō, "Menstruation sutra") from, most probably, Muromachi period-a sūtra which describes a road to salvation of women who, because of their menstrual blood which dishonours soil and water, end up in Hell by default. I chose two comments from the beginning of the $19^{\text {th }}$ century, which explain its contents in this way:

"Because they were born as women, their aspirations to Buddhahood are weak, and their jealousy and evil character are strong. These sins compounded become menstrual blood, which flows in two streams each month, polluting not only the earth god but all the other deities as well. Thus after death they will certainly fall into this Hell, where they will undergo unlimited suffering."

"All women, even those who are the children of high families, have no faith and conduct no practices, but rather have strong feelings of avarice and jealousy. These sins are thus compounded and become menstrual blood, and every month this flows out, polluting the god of the earth in addition to the spirits of the mountains and rivers. In retribution for this women are condemned to the Blood Pool Hell." (Takemi 1983, 7)
} 


\section{Itako or ogamisama in Tōhoku Region}

Wandering shamanesses had been a common sight until the beginning of the twentieth century. They visited villages in groups of 5 to 6 , especially in the time before the autumn harvest. Their duties were the following: communication with spirits, gods and souls of the dead; predicting future by means of the trance, prayers to heal the diseased; purification of new buildings, wells, hearths and stoves (Hori 1968, 202-3). Although, it seems that these wandering shamanesses almost disappeared in modern Japan, their trace can be found even today in Tōhoku region.

Beside the service in their villages, shamanesses gather once a year in various places throughout Japan ${ }^{18}$ during the Buddhist celebration Jizo bon ${ }^{19}$. One of the most famous locations is the mountain Osore, an inactive volcano, which has been believed to be the habitat of spirits and the world of the dead since ancient times. On the day of Bodhisattva Jizo , on the $24^{\text {th }}$ of the sixth month of the lunar calendar, elderly men and women from the surrounding villages start climbing the mountain, carrying special rice balls which they lay by the statues and other representations of Jizo placed along the way. Since Muromachi period there is the belief that the spirits of dead children build stūpa ${ }^{20}$ from pebbles, and this activity ensures them good karma for entering heaven. This is especially true for very small children who have not managed to accumulate enough good deeds by serving their parents and community. Every woman who has lost a child builds stüpa from pebbles and in that way helps her child deserve admission to heaven (Hori 1968, 208).

Some Japanese people still believe that the spirits of the small or unborn children (Jap. mizuko) are somewhat malign, since they failed to accumulate their good karma. For some reason they act as goryō, the evil spirits; they cause

\footnotetext{
${ }^{18}$ There are a few holly mountains and temples in the north of Honshu, like the mountain Osore, Jizō chamber in Kanagimachi in Aomori prefecture, and Hachiyō temple in Fukushima prefecture (mountains Tateyama, Hakusan, Kinpu and Nachi).

${ }^{19} \mathrm{Jiz} \bar{o}$ bon is a celebration encompassing the belief in the Bodhisattva Jizō and O-bon festival, the most famous annual Japanese Buddhist celebration devoted to the spirits of the dead. In Tohoku region O-bon festival takes place from the $13^{\text {th }}$ to $15^{\text {th }}$ of the seventh month in the lunar calendar, while Jizō bon takes place on the day of Bodhisattva Jizō in the sixth month of the lunar calendar. Jizo is believed to be the patron of the souls of the dead, especially children, and he has been popular in Japan since the tenth century (Hori 1968, 207-8).

${ }^{20}$ The word stūpa (Skt) originally meant a grave-mound over the remains of Buddha and Buddhist holy people, and later hemispherical buildings, main monuments of Buddhist sacral architecture. They are also symbols related to important events in Buddha's life or they symbolize holly texts and other things (Ježić et al. 2001, 123).
} 
diseases, mental difficulties, family quarrels, etc., so the ritual mizuko kuyō has the role of mollifying them ${ }^{21}$. As much as there are warnings that mizuko kuyo understood in this way is not in the spirit of Buddhism because the purpose of the rite is to ease one's soul and accept Buddha's mercy, Smith writes that while he was investigating the background of mizuko kuyo in Japan, he was astonished to realize the extent to which blaming the spirit of mizoko for eventual accidents is widespread among Japanese women (especially those who had experienced abortion in their life). Life troubles are often experienced as a punishment of an evil spell (Jap, tatari) of an aborted child (Smith 1988, 15).

During Jizo bon celebration, more than thirty shamanesses set off to the main entrance of a Buddhist temple on Mount Osore. They are approached by women who have lost their husbands, children or grandchildren with questions related to commemoration and establishing communication with their souls. They sit in a circle around a shamaness and listen to what the dead say through her mouth. Itako answers every question separately, falling into a trance from the morning to the evening. Naturally, she charges money for that, but the prices are not unaffordable to general public - as stated by Hori $(1968,211)$, they range from a few cents to several tens of US dollars. On a regular day every trance lasts an hour or more on the average, while on the festivals, it lasts only five to ten minutes.

Reasons why people come to these settings are numerous: a yearning for remembrance, comfort from grief, psychological problems or simply a desire for advice or reassurance. When she is given specific information such as a name, the medium begins keening in a singsong voice to initiate a trance. Sometimes her voice abruptly changes or her pattern of moving shifts, indicating that spirit contact has been made. Even though the messages form the spirits are relayed in a dialect which even natives have difficulty understanding, many people leave

\footnotetext{
${ }^{21}$ The tradition of mizuko kuyō, whose main patron is Jizo has existed in Japan for around two hundred years. Mizuko or mizugo (Jap, ko, "a child"; Jap, mizu, "water") is a term which since Edo period (1603-1868) has denoted spontaneously or intentionally aborted human embryos, prematurely born foetuses, babies died of natural causes immediately after birth and babies victims of infanticide. $K u y \bar{o}$ is a Buddhist term which first meant giving alms to a priest for the benefit of the deceased; today it means worshipping of the dead in general. The term literally means "to offer and to heal" (Smith 1988: 10), i.e. offer prayers for healing the soul of the dead as well as the recovery of an injured soul, primarily of a mother, but also of other family members. The rite may be performed once, but also a few times, depending on the temple where it is performed. It is often performed on anniversaries of deaths, when people can ask for a private rite, but usually, the rite is devoted to all mizuko. The custom is that the family should offer presents to the temple, which are mostly some arbitrary sums of money (see Lakić Parać 2013 for more about this topic).
} 
Mount Osore satisfied that they have indeed reached the spirit of dead spouses or children (Ross 1996, 19).

When the hectic festival is over, the itako return to their village homes, where they continue to be quietly consulted throughout the year on tasks ranging from calling down household gods to healing the sick. If a person falls ill she attempts to identify the spirit that is causing the sickness and if she is successful, she rids the body of the intruder, thus curing the patient of the disease (Ross 1996, 20).

\section{Conclusion}

In his book Lewis (2003) analyses "possession" and shamanism as a social (and political), and not exclusively cultural phenomenon, investigating which social groups are the most sensitive to spirits and what are social consequences of it. By explaining different types and functions of mystical experience, he divides them into main (central) and marginal (peripheral), emphasizing the difference between powerful cults of possession dominated by men whose aim is to maintain the wellestablished morale and order, and marginal, heretic forms of ecstasy created as an expression of the protest of the oppressed, especially women. The main difference between these two categories is not their therapeutic (or medical) effect, but the types of spirits who inspire them: on one side we have spirits who directly support public morale and order (hotoke in Japan), and on the other hand the ones who are their threat (goryō and mizuko in Japan).

Lewis concluded that the purpose of exorcism is the control over women, especially in gender-biased, rigid, patriarchal and traditional cultures. He gave an example of a famous Japanese novel from the $11^{\text {th }}$ century, Genji monogatari, in which Murasaki Shikibu describes a few episodes of spirit possession (Jap, mononoke) among court ladies. In ancient patriarchal, polygamous Japanese society, mononoke was "a feminine weapon" which women used to resist incest offences and unwanted attention from male nobility. These tendencies did not develop into a strong independent female cult in ancient Japan, but they were kept under control by exorcist practices usually by male clergy (Lewis 2003, 16).

It is true that in the past Japanese female mediums had an important role in the religious life of the Japanese, but they were always semi-institutionalized figures. In medieval Japan almost all Buddhist priests had a shamaness or her substitute by their side, whom they used in their exorcist rituals as a medium through which a 
vengeful spirit spoke and sent his messages. However, the character and the function of Japanese shamanesses has developed and changed through history, and finally resulted in the appearance of a few trends, the most important being: shamanesses are thus professional mediums associated with a Buddhist sect or a Shinto temple (jinjamiko), sato-miko who become shamanesses through a series of special initiation temptations and trainings administered by their masters, and jussha or gyōja who are associated with modern religious phenomena or new religious movements such as, for example, Tenrikyō of a charismatic Nakayama Miki.

Miki was determined to offer to women an alternative realization of pregnancy and childbirth, opposite to the common practice, and in doing so she created a community of women interconnected by a common belief. Instead of traditional beliefs and treatments, she promised a safe delivery of a baby as a result of believing in her and her actions. She treated childbirth as a natural event which does not require the expectant mother to be isolated because of her impure state, encouraging the women to continue with their normal social life. With her alternative attitudes, Miki announced changes in relationships between sexes, which she ultimately demonstrated through her own marriage and relationship with her husband.

Therefore, we see that historically speaking, in Japan, female mediums in the past served only as means through which a spirit or a deity who possessed the victim spoke, but their role changed through time and transformed from a passive to an active one.

What is crucial is that some very specific circumstances in the lives of these women made them become shamanesses. When itako in the north-east of Japan is considered, the total or partial blindness defined their lives. Immediately after the birth of a blind girl, or if blindness occurred later (the ideal time was before the first menstruation, i.e. before a girl "became a woman" 22 ), the parents knew that they would give her to an older ogamisama for training. This is how they ensured a secure future for the girl and a job as a full-fledged member of the community after they passed away. Since they were not able to become full-fledged work force, they were exposed to physical and social discrimination (they were given a

\footnotetext{
${ }^{22}$ In pre-war Japan with their first menstruation girls became women in the sense that they went from their homes to serve in other households, got married and started actively participating in hard agricultural work (Kawamura 2003, 263).
} 
pejorative nickname mekura or "dark eyes"). This social component of blindness is actually a prerequisite for a woman to become a shamaness and to start doing this "job" (the community, but also they themselves, called this job mekura's business). The practice of giving a blind woman a social position of ogamisama and, in this way, accepting her as a full-fledged member of a community gradually became an institutionalized custom of a local community.

Kamisama begins her fujo life by special psychosomatic problems which she cannot control at first. People in her surrounding proclaim her sick; her behaviour is deviant because it does not let her function normally in her family and society; she demonstrates some outstanding extremes in her behaviour which, from very shy and depressive, gradually becomes extremely extrovert and rapturous. In a short time her behaviour starts being interpreted as a consequence of spirit possession, and she starts associating her psychosomatic states with the effects of positive (kami) and negative (hotoke) powers. Over time, after she has mastered shamanistic techniques of possession and becomes experienced in her "job", she will learn to control her own psychosomatic states. She will associate positive states of her soul with the effects of positive powers and negative states with the effects of negative powers. In this way she will re-interpret the existing folk beliefs for her own benefit.

Ogamisama and kamisama are figures who, by helping others each in her own way, actually help themselves the most. Former ones as blind people, and latter ones as people suffering from psychosomatic disorders, they affect their marginal social position by applying the existing cultural imaginaries which gives them the role of a social mediator. Women, who would otherwise be on the margins of society, rejected and isolated because they do not contribute to the community, managed to position themselves between the worlds of the living and the dead, the worlds of people and deities. In that way they made their role in society not only important, but also crucial for the community.

\section{References}

Anderson, Richard, and Elaine Martin. 1997. "Rethinking the Practice of Mizuko Kuyō in

Contemporary Japan: Interviews with Practitioners at a Buddhist Temple in Tokyo." Japanese Journal of Religious Studies 24 (1-2):121-43.

Blacker, Carmen. 1999. The Catalpa Bow: A Study of Shamanistic Practices in Japan.

Tokyo: Japan Library. 
Bocking, Brian. 1996. A Popular Dictionary of Shinto. Richmond: Curzon Press.

Brooks, Anne Page. 1981. "Mizuko kuyō and Japanese Buddhism.” Japanese Journal of Religious Studies 8 (3-4): 119-47.

Dubois, Thomas A. 2009. An Introduction to Shamanism. Cambridge: Cambridge University Press.

Eliade, Mircea. (1964) 1985. Šamanizam i arhajske tehnike ekstaze (Le Chamanisme et les techniques archaïques de l'extase). Novi Sad: Matica Srpska.

Hardacre, Helen. 1997. Marketing the Menacing Fetus in Japan. Berkley, Los Angeles and London: University of California Press.

Hori, Ichirō. 1968. Folk Religion in Japan. Continuity and Change. Chicago and London: The University of Chicago Press.

—. 1975. "Shamanism in Japan.” Japanese Journal of Religious Studies 2(4): 231-87.

Hultkrantz, Åke. 1997. "Some Points of View on Ecstatic Shamanism, with Particular Reference to American Indians.” Shaman 5 (1): 35-46.

Ježić, Mislav, Milka Jauk-Pinhak, and Klara Gönc Moačanin. 2001. Istočne religije. (skripta za studente), Filozofski fakultet, Katedra za indologiju, Zagreb.

Kawamura, Kunimitsu. 2003. "A Female Shaman's Mind and Body, and Possession." Asian Folklore Studies 62: 255-87.

Koić, Elvira. Psihosomatski poremećaji. Predavanja za srednje škole. (Psychosomatic Disorders. High School Lecture ). PP. Accessed November 24, 2014. https://www.google.hr/?gfe_rd=cr\&ei=Xv5yVLqODcmI8QeumoH4Cw\&gws_rd=ssl\# $\mathrm{q}=$ psihosomatski+poreme $\% \mathrm{C} 4 \% 87$ aji, + koi $\% \mathrm{C} 4 \% 87$.

Lakić Parać, Iva. 2013. "Sinkretičke religijske prakse na području Yamagate (Japan) (Syncretic Religious Practices in Case of Yamagata, Japan)." Studia Ethnologica Croatica 25: 253-81.

Lewis, I.M. 2003. Ecstatic Religion. A Study of Shamanism and Spirit Possession. London and New York: Routledge Taylor \& Francis Group.

Matsumura, Kazuo. 2006. "Ancient Japan and Religion.” In Nanzan Guide to Japanese Religions, edited by P.L. Swanson and C. Chilson, 131-43. Honolulu: University of Hawaii Press.

Morris, Brian. 2006. Religion and Anthropology. A Critical Introduction. Cambridge: Cambridge Universtiy Press.

Nakamura, Hajime. 2012. Načini mišljenja istočnih naroda: Japan - India, China, Tibet, Japan (Ways of Thinking of Eastern Peoples - India, China, Tibet, Japan), Vol 2, translated by Goran Kardaš. Zagreb: Demetra.

Raveri, Massimo. 2006. Itinerari nel sacro. L'esperienza religiosa giapponese. Venice: Libreria Editrice Cafoscarina. 
Iva LAKIĆ PARAĆ: Social Context of the fujo: Shamanism in Japan ...

Ross, Catrien. 1996. Japanese Ghost Stories. Spirits, Hauntings and Paranormal Phenomena. Tokyo: Tuttle Poblishing.

Smith, Bardwell. 1988. "Buddhism and Abortion in Contemporary Japan: Mizuko Kuyō and the Confrontation with Death." Japanese Journal of Religious Studies 15 (1): 3-24.

Takemi, Momoko. 1983. “Menstruation Sutra Belief in Japan.” Japanese Journal of Religious Studies 10 (2-3).

Tamaru, Noriyoshi, and David Reid. 1996. Religion in Japanese Culture. Where Living Traditions Meet a Changing World. Tokyo, New York, London: Kodansha International.

Vukelić, Deniver. 2012. "Problemi identifikacije iidentiteta u hrvatskih 'šamana's kraja 20. i početka 21. stoljeća (Problems of Identification and Identity of Croatian 'Shamans' from the End of the $20^{\text {th }}$ and the Beginning of the $21^{\text {st }}$ Century)." Studia Ethnologica Croatica 24: 167-94.

Werblowsky, Zwi R.J. 1991. "Mizuko kuyō - Notulae on the Most Important 'New Religion' in Japan.” Japanese Journal of Religious Studies 18 (4): 295-354.

Watanabe, Shoko. 1968. Japanese Buddhism: A Critical Appraisal. Tokyo: Kokusai Bunka Shinkokai.

Winkelman, Michael. 1999. “Altered States of Consciousness and Religious Behaviour.” In Anthropology of Religion. A Handbook, edited by Stephen D. Glazier, 393-429. Westport, London: Praeger. 